\title{
Molecular interaction studies of secondary metabolites of the lichen Asahinea scholanderi with acetylcholinesterase and butyrylcholinesterase
}

\section{Ureña-Vacas, I.M. ${ }^{a}$, De Vita, S. ${ }^{b}$, González-Burgos, E. ${ }^{a}$, Bifulco, G. ${ }^{b}$, Gómez-Serranillos, M.P. ${ }^{a}$}

a Department of Pharmacology, Pharmacognosy and Botanical, Faculty of Pharmacy, Universidad Complutense de Madrid, Plaza Ramon y Cajal s/n, Ciudad Universitaria, 28040, Madrid, Spain.

${ }^{b}$ Department of Pharmacy, University of Salerno, Via Giovanni Paolo II 134, 84084, Fisciano (SA), Italy.

\section{Introduction}

Lichens, due to their symbiotic origin, have important properties for pharmacological research. This study focuses on the lichen Asahinea scholanderi (Llano) W.L. Culb. \& C.F. Culb, which belongs to Parmeliaceae family and specifically to Cetrarioid clade.

According to its morphology, Asahinea scholanderi has a foliose growth form. These lichens are more widely distributed in North America and Siberia. This species grows over boulders and on humus in the tundras.
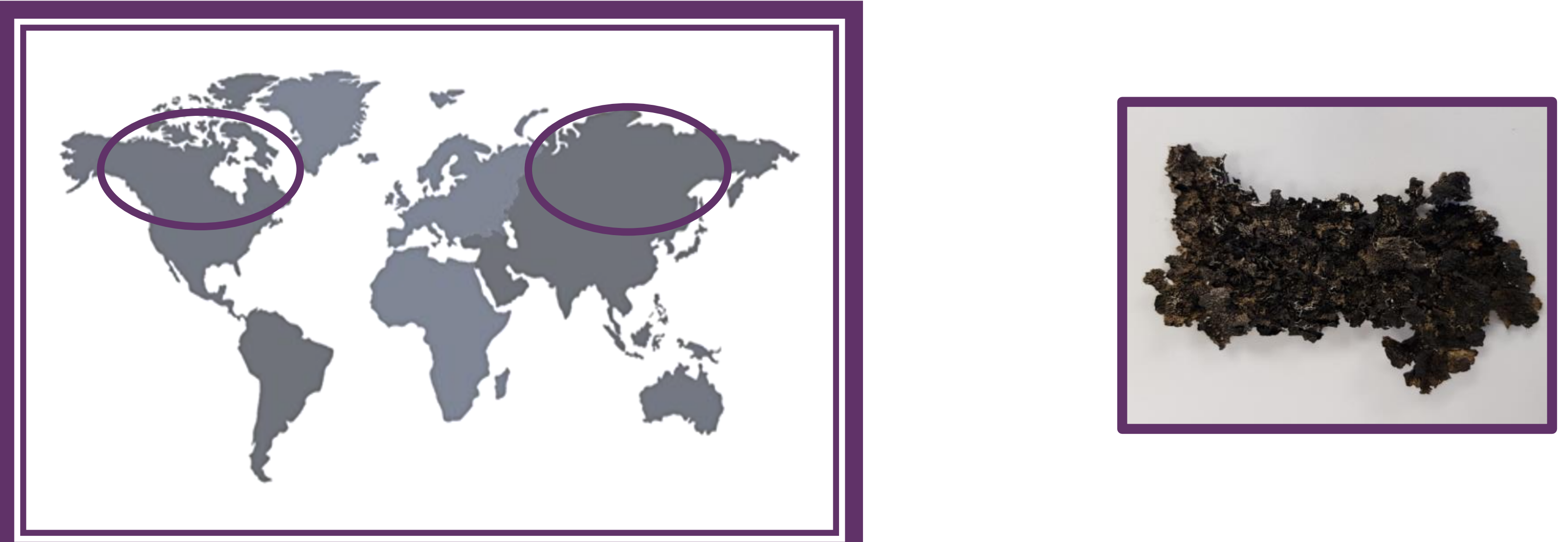

The etiology of Alzheimer's disease and other dementias is related with the degeneration of cholinergic neurons. Disruption in cholinergic neurotransmission affects to cognitive processes as memory and learning. The enzymes acetylcholinesterase (AChE) and butyrylcholinesterase (BuChE) degrade acetylcholine into the inactive metabolites. Therefore, inhibitors of cholinesterase enzymes are key in the prevention of Alzheimer's disease progression. Previous works with Asahinea scholanderi extracts showed IC50 values $0.11 \mathrm{mg} / \mathrm{mL}$ for AChE and $0.29 \mathrm{mg} / \mathrm{mL}$ for BuChE inhibitory activities.

\section{Objectives}

* Identification of the major bioactive metabolites of Asahinea scholanderi

* Delve into the study of the inhibition of the enzymes acetylcholinesterase (AchE) and butyrylcholinesterase (BuchE) by the secondary metabolites from Asahaniea scholanderi.

\begin{tabular}{|c|c|}
\hline & Material and methods \\
\hline 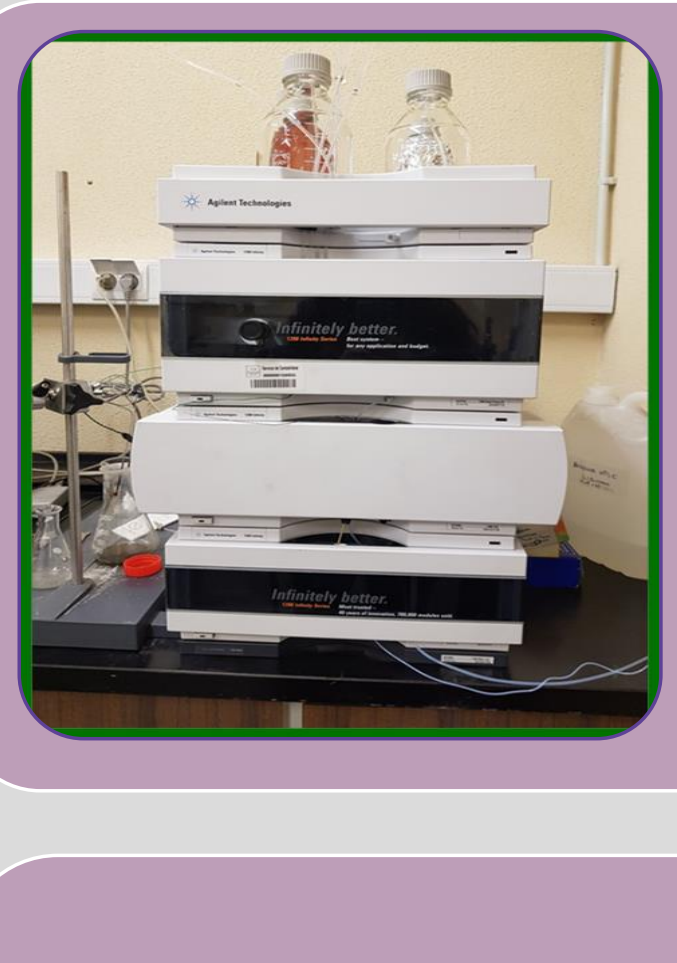 & $\begin{array}{l}\text { HPLC: Agilent } 1260 \text { instrument. Column: } \\
\text { reversed-phase Mediterranea Sea } 18 \text { column } \\
(150 \mathrm{~mm} \times 4.6 \mathrm{~mm}, 3 \mu \mathrm{m}) \text {. Phases: (A)->1\% } \\
\text { orthophosphoric acid in milli-Q water ,(B)- } \\
\text { >UHPLC-methanol. Flow rate: } 0.6 \mathrm{ml} / \mathrm{min} \text {. UV } \\
\text { spectrum }(190 \text { and } 400 \mathrm{~nm})\end{array}$ \\
\hline & $\begin{array}{l}\text { Docking studies } \\
\text { Protein structures using Protein Preparation } \\
\text { Wizard tool available in Schrödinger Suite. } \\
\text { Chemical structures were built using Maestro } \\
\text { Build Panel and processed with LigPrep. } \\
\text { Molecular docking experiments using Glide 20- } \\
23 \text { in the Extra Precision mode (XP) software. }\end{array}$ \\
\hline
\end{tabular}

\section{Results}

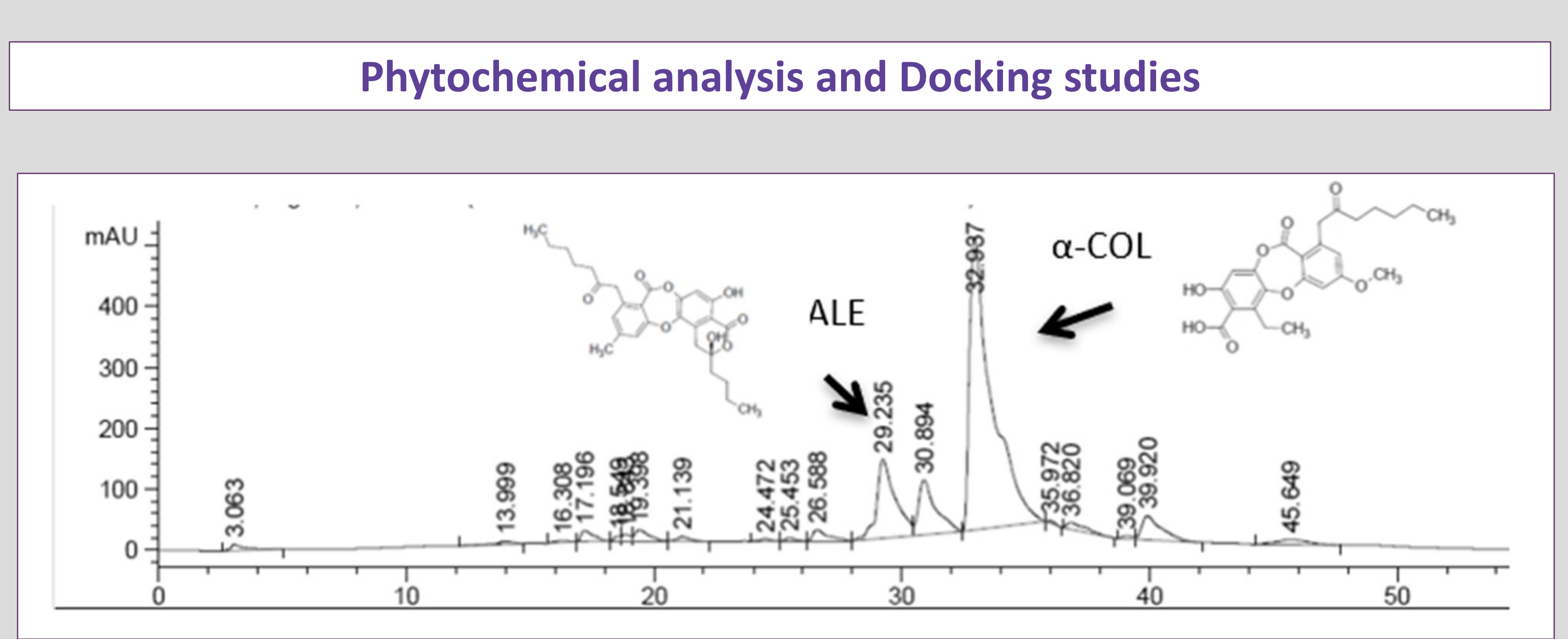

Figure 1. Representative HPLC chromatogram Asahinea scholanderi methanol extract at $254 \mathrm{~nm}$.
Table 1. Predicted binding affinity between the compounds and enzymes( AchE and BuChE).

\begin{tabular}{|c|c|c|c|c|}
\hline \multirow{3}{*}{ Compound } & \multicolumn{2}{|c|}{ AchE } & \multicolumn{2}{|c|}{ BuchE } \\
\hline & \multicolumn{4}{|c|}{ Docking score (kcal/mol) } \\
\hline & With $\mathrm{H}_{2} \mathrm{O}$ & Without $\mathrm{H}_{2} \mathrm{O}$ & With $\mathrm{H}_{2} \mathrm{O}$ & Without $\mathrm{H}_{2} \mathrm{O}$ \\
\hline Acetylcholine & -8.5 & -7.4 & -4.1 & -5.1 \\
\hline $\begin{array}{l}\text { Donepezil (AchE) } \\
\text { Naphthamide(BuchE) }\end{array}$ & -18.5 & -15.7 & -15.9 & -10.5 \\
\hline Alectoronic acid & -10.8 & -11.1 & -6.2 & -6.6 \\
\hline Alpha-collatolic acid & -7.2 & -9.9 & -5.5 & -6.7 \\
\hline
\end{tabular}

A)

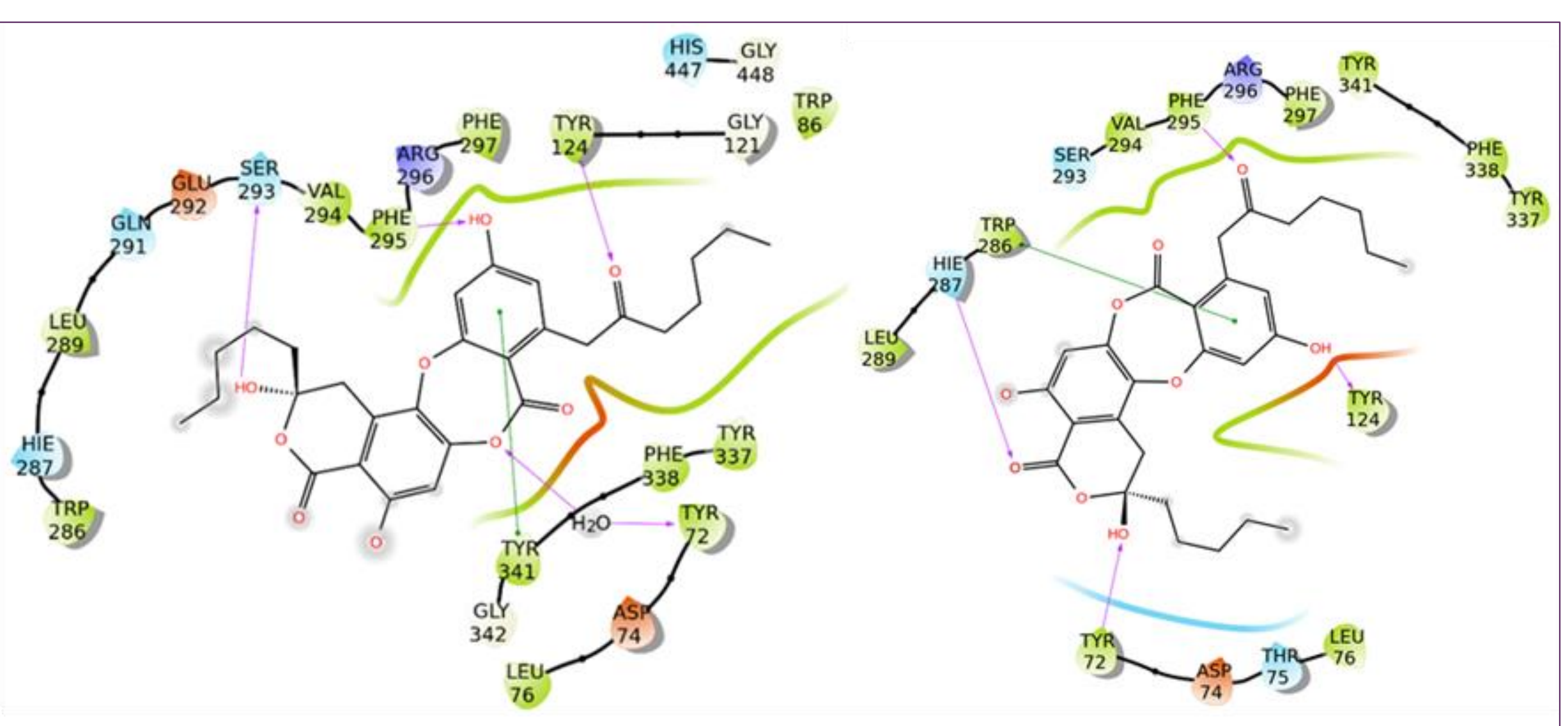

B)

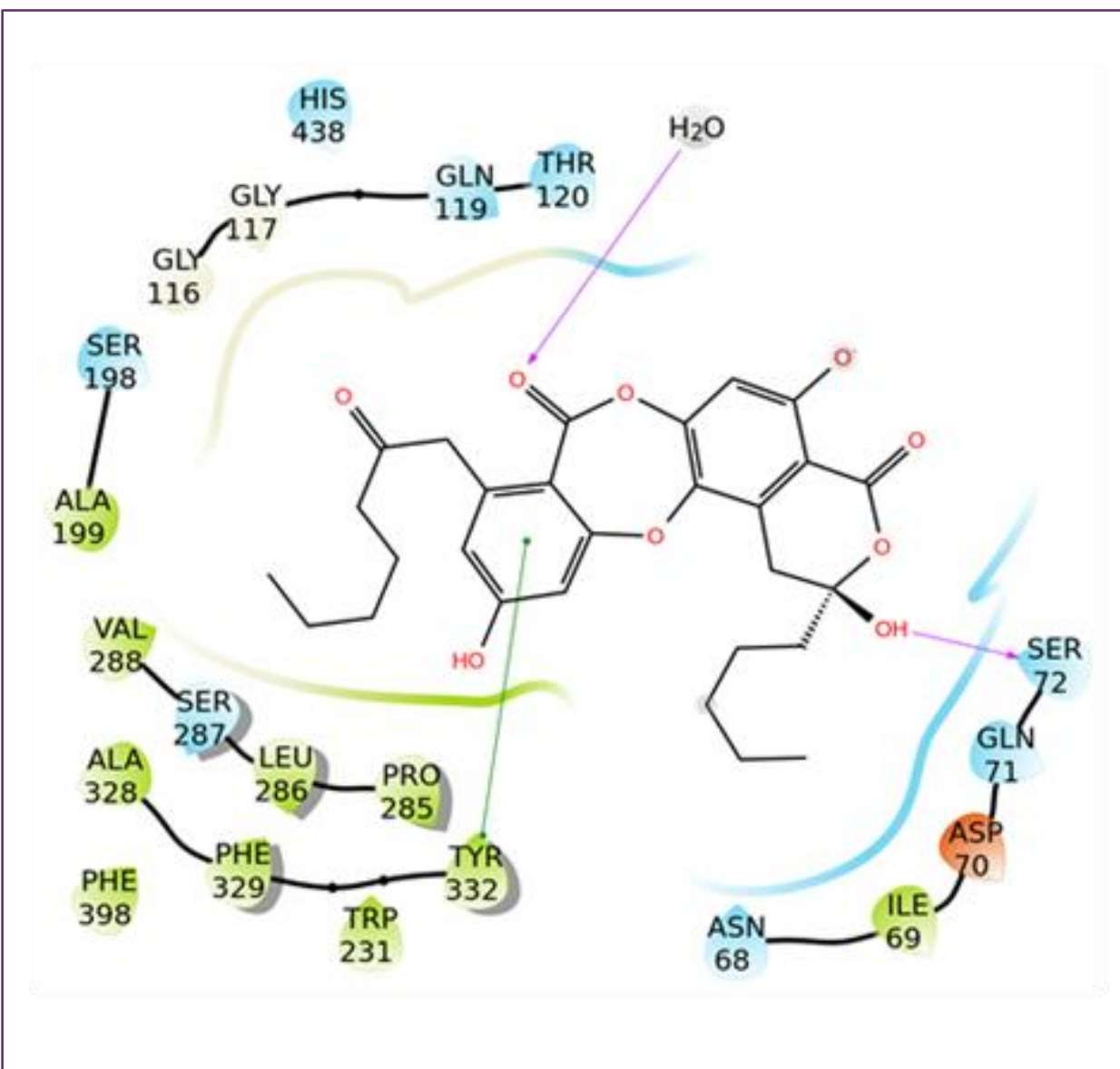

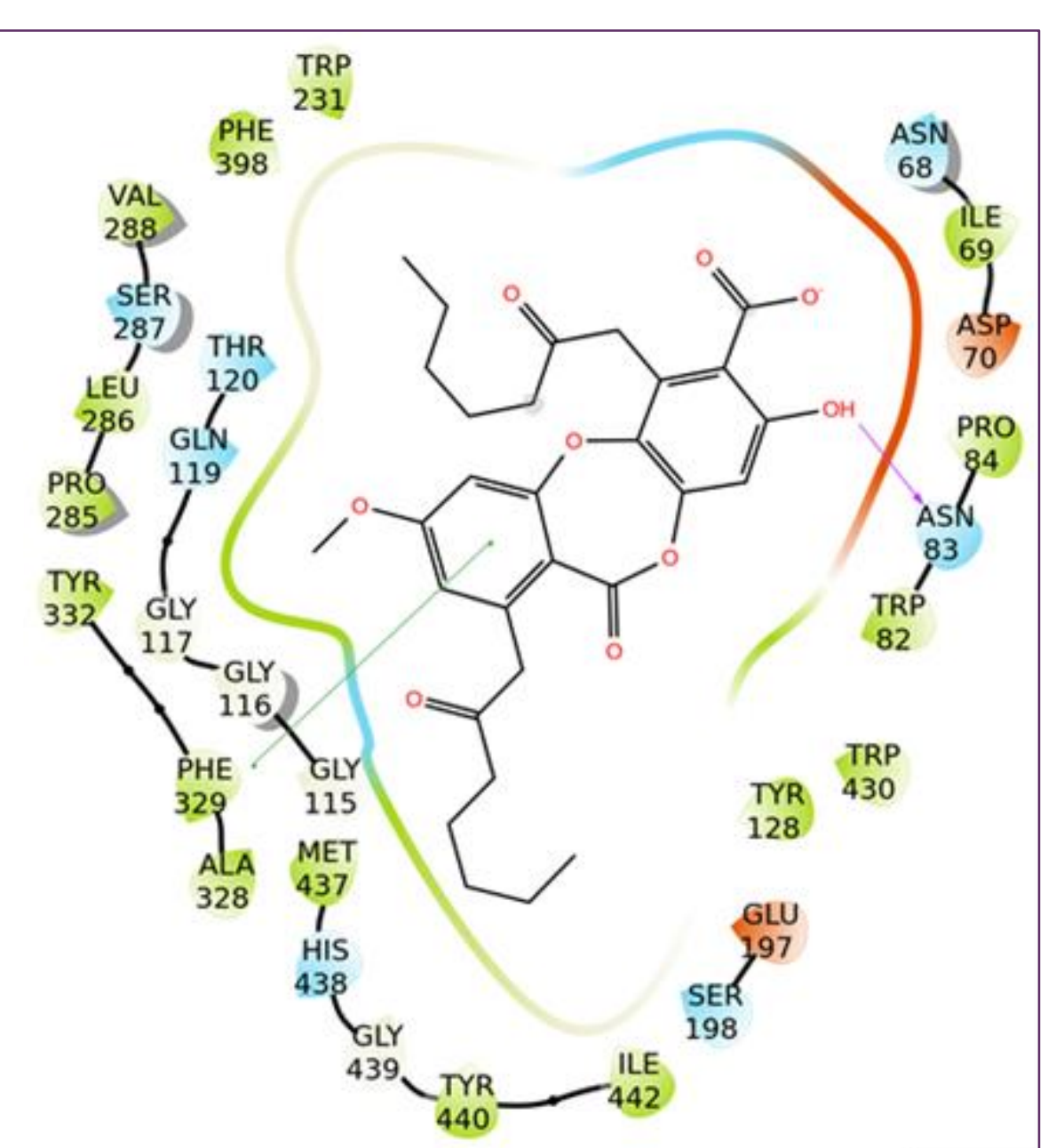

Figure 2. Protein-ligand interactions for alectoronic acid: A) with AChE B) with BuChE, with (left) and without (right) water molecules included in the binding site. Hydrogen bonds are represented by pink arrows and $\pi-\pi$ stackings are represented

Figure 2. Protein-ligand interactions for alectoronic acid: A) with AChE B) with BuChE, with (left) and without (right) water molecules included in the binding site. Hydrogen bonds are represented by pink an
by green lines. Hydrophobic residues are in green, polar residues are in cyan, negatively charged residues are in red, positively charged ones are in blue, glycine residues and water molecules are in white.

\section{Conclusions}

- The major compounds of Asahinea scholanderi identified by HPLC were alectoronic acid and collatolic acid.

- Alectoronic acid exhibited strong interactions with both AChE and BChE with and without water molecules in the binding site, even more than Ach.

- These molecules should be further investigated as cholinesterase inhibitors for the prevention and treatment of Alzheimer's disease.

\section{Bibliography}

* de Paz GA, Raggio J, Gómez-Serranillos MP, et al. HPLC isolation of antioxidant constituents from Xanthoparmelia spp. J Pharm antioxidant constituents from Xanthopa

Biomed Anal. Oct 2010;53(2):165-71. W. Protein and ligand preparation: parameters, protocols, and influence on virtual screening enrichments. J Comput Aided Mol 2013,27(3):221-234. doi:10.1007/s10822-013-9644-8

\section{6th International Electronic Conference on Medicinal Chemistry 1-30 November 2020


